\title{
40. BOTTOM CURRENTS AND ICE RAFTING IN THE NORTH ATLANTIC: INTERPRETATION OF NEOGENE DEPOSITIONAL ENVIRONMENTS OF LEG 49 CORES ${ }^{1}$
}

\author{
Alexander N. Shor, MIT/WHOI Joint Program in Oceanography, Woods Hole Oceanographic Institution, \\ Woods Hole, Massachusetts \\ and \\ Richard Z. Poore, Branch of Paleontology and Stratigraphy, United States Geological Survey, Menlo Park, California
}

\begin{abstract}
DSDP Leg 49 provides new data bearing on two important problems concerning the Neogene environment of the North Atlantic. First, our interpretation of three northern sites $(407,408$, and 409) supports previous interpretations, based on Leg 38 data, which conclude that the deep circulation of the eastern North Atlantic (and possibly the entire North Atlantic) did not attain its present configuration until at least the early Miocene. This is considerably younger than previous studies had suggested. For example, Berggren and Hollister $(1974,1977)$ inferred a deep connection between the Norwegian Sea and the North Atlantic about 50 m.y. ago.

The second problem of interest to geologists and climatologists is the maximum southward extent of ice rafting in the North Atlantic during the Pliocene, and the date of initiation of ice rafting. Data from Site 410 $\left(45^{\circ} \mathrm{N}\right.$ latitude) provide a minimum southern limit for the Pliocene iceberg drift, and support the date of 3 m.y.B.P. (Berggren, 1972) for the initiation of extensive Northern Hemisphere glaciation.
\end{abstract}

\section{INTRODUCTION}

\section{Bottom Circulation in the Eastern North Atlantic}

The modern bottom circulation in the eastern North Atlantic is controlled primarily by the flow of dense water from the Norwegian Sea into Iceland Basin through Faroe Bank Channel (Crease, 1965) and across several sills about 500 meters deep on the Iceland-Faroe Ridge (Worthington and Volkmann, 1965; Tait, 1967; Worthington, 1970). The southward flow along southeastern Iceland and the east flank of Reykjanes Ridge is well documented by both hydrographic data (Fuglister, 1960; Worthington and Wright, 1970) and direct current measurements (Steele et al., 1962; Shor, 1977) as far south as $53^{\circ} \mathrm{N}$, where the current turns to flow westward through Charlie Gibbs fracture zone into the western basin (Worthington and Volkmann, 1965; Worthington and Wright, 1970; Garner, 1972; Shor et al., in preparation; see also Le Pichon et al., 1971 for a differing interpretation). Upon entering the western basin, the current apparently turns northward, flowing along the western flank of the ridge (Worthington and Volkmann, 1965; Davies and Laughton, 1972; Berggren and Hollister, 1974). Direct current measurements are lacking in this region, however.

Before DSDP Leg 38 (Talwani, Udintsev, et al., 1976), hypotheses concerning the initiation date of overflow of Norwegian Sea water into the North Atlantic relied heavily on studies of sediments in the western North Atlantic basins

${ }^{1}$ WHOI Contribution No. 4190.
(Vogt, 1972; Berggren and Hollister, 1974; and others). The most popular of these hypotheses correlates the initial deep connection between the North Atlantic and the Norwegian Sea with horizon $A$, the ubiquitous Eocene set of seismic reflectors in the Atlantic which have been shown to correspond (in part) to an erosional hiatus on the western margin of the North American basin (Ewing and Hollister, 1972; Tucholke, 1978). These studies indicate that horizon $A$ results from a major reorganization of the deep circulation; but the link between this reflector and flow originating in the Norwegian Sea is poorly documented.

Results from DSDP Leg 38 strongly suggest that bottom flow from the Norwegian Sea into the eastern North Atlantic did not begin until after mid-Oligocene time. Results of drilling at Sites 336 and 352 (Figure 1) suggest that the Iceland-Faroe Ridge was elevated above sea level until about 30 m.y.B.P., and that Site 336 , which is now 1300 meters below sea level, was emergent during the late Eocene (Talwani, Udintsev, et al., 1976). Thus, it appears unlikely that the origin of horizon $A$ can be linked to formation of a deep connection between the North Atlantic and the Norwegian Sea east of Reykjanes Ridge.

We cannot address directly here the question of whether bottom water flow began earlier across the Iceland-Greenland Ridge (Denmark Strait) than across the Iceland-Faroe-Scotland Ridge. The indirect evidence supporting such a break (middle Eocene) is basically the erosional event associated with horizon $A$ around the western margin of the North American basin (Ewing and Hollister, 1972; Tucholke, 1978), and the evidence from vertebrate paleontology that faunal migration patterns 

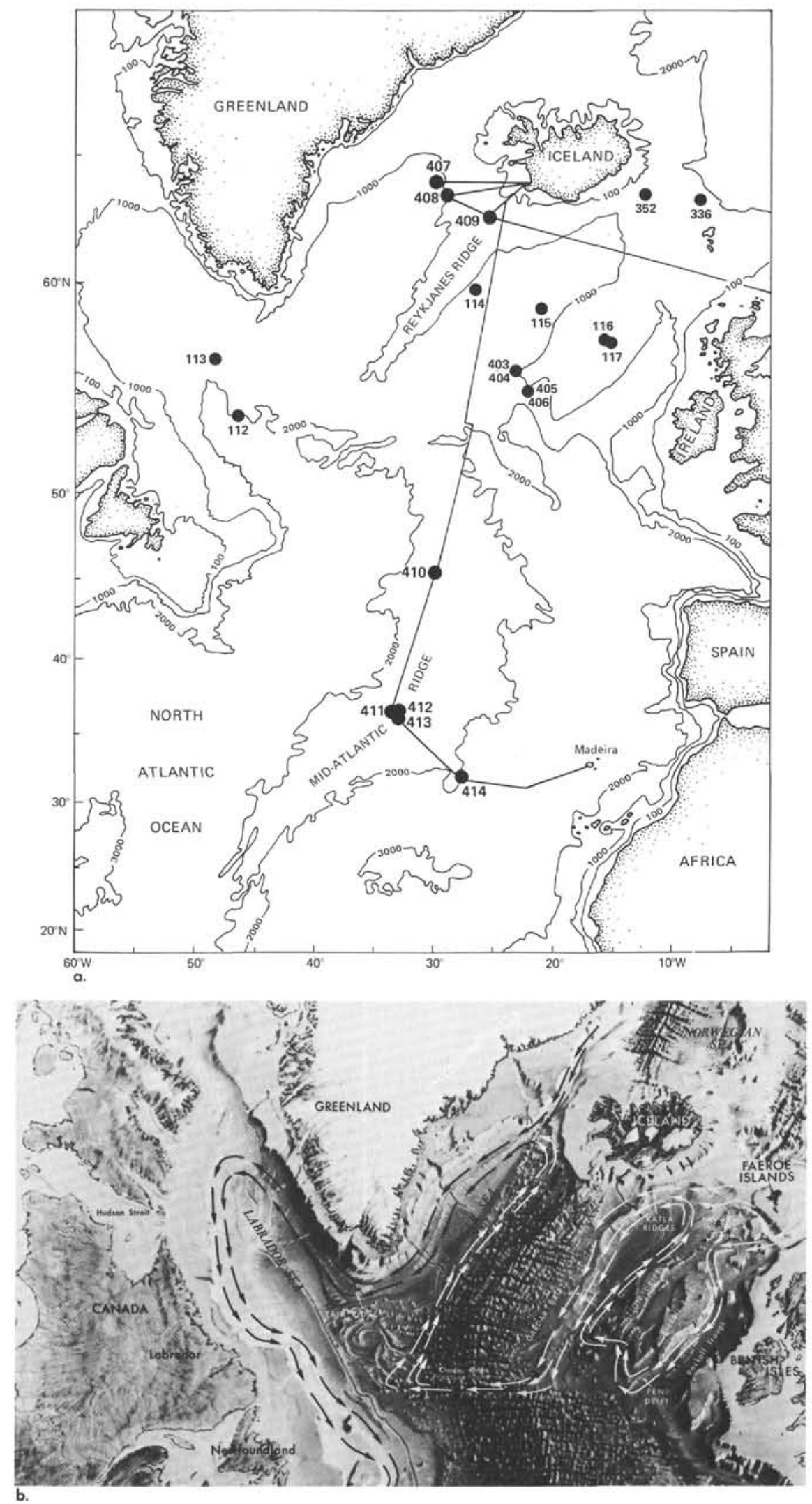

Figure 1. Track chart of the northern North Atlantic Ocean, showing locations of Leg 49 sites and other DSDP sites referred to in text. Inferred flow of bottom currents in the northern North Atlantic ocean. Major sediment drifts associated with bottom circulation are illustrated. Physiographic diagram by $M$. Tharp. Figure reproduced from Hollister et al., 1978. 
changed markedly about 50 m.y.B.P. between Europe and North America (McKenna, 1972, 1975; Berggren and Hollister, 1974).

Weyl (1968) and, more recently, Kellogg $(1976,1977)$ have discussed the variability of Norwegian Sea overflow during the Pleistocene. Although they present no direct evidence to substantiate their arguments, they infer that bottom-water formation ceased in the Norwegian Sea during glacial maxima (Kellogg, 1977, suggests most of the past 450,000 years), owing to the southward shift of the northern extension of the Gulf Stream (North Atlantic Current). Their contention is that this southward shift stopped the flow of the Norwegian Current during glacial periods, and that this in turn led to termination of bottom water production because the source of saline water was cut off.

Recent work by Reid (1977; written communication) suggests that the Mediterranean outflow may be an important source of the saline water of the Norwegian Current today. If so, then there is no apparent reason why Mediterranean water, which Reid observes to rise from intermediate levels in the Atlantic to the surface of the Norwegian Sea along isopycnal surfaces, should not flow northward even during glacial periods. The properties of bottom water formed in this manner might vary with changes in the proportion of water coming from eastern and western sources, but one might argue that an increased proportion of Mediterranean water flowing northward during glacial periods would raise the salinity sufficiently (and hence density) to allow production of dense Norwegian Sea Deep Water to continue, even if, because of sea ice cover, surface cooling were not as efficient.

Although we do not know, we do feel (in contradition to Weyl [1968] and Kellogg [1976, 1977]) that there is a possibility that overflow continued through glacial periods. What little information we have concerning the variation of overflow with time before the Pleistocene is limited principally to sediment drift morphology and drilling results, and is summarized below.

\section{Sediment Drifts of the North Atlantic}

Several elongate sediment bodies in the northern North Atlantic have been ascribed by various authors to deposition by bottom currents. These include the Feni and Hatton drifts around Rockall Plateau, the Gardar drift complex along the eastern flank of Reykjanes Ridge, and the Eirik drift along the southeast margin of Greenland (Figure 1) (Johnson and Schneider, 1969; Jones et al., 1970; Johnson et al., 1971; Ruddiman, 1972). These sediment drifts (or ridges) are acoustically transparent features, elongated parallel to the bottom current flow (where it is known), and are often mantled with "mud waves" having wavelengths of one to two kilometers and amplitudes of a few tens of meters. The ridges themselves are often hundreds of kilometers long, tens of kilometers across, and vary from sharply peaked to slightly convex. Sediment accumulation rates are generally high; a rate of $12 \mathrm{~cm} / 1000$ years was determined through 600 meters of sediment overlying basement at Site 114 on the Gardar drift complex.

Two studies of seismic reflection profiles in the eastern North Atlantic provide most of the information currently available on the age of sediment drift development in the basin (Ruddiman, 1972; Roberts, 1975). Both these authors argue that all of the sediment drift morphology is Oligocene or younger, according to the inferred age of acoustic reflectors within the sediment column. Ruddiman (1972) suggests that the development of modern current deposits underlying Gardar drift began in the Miocene (17 or 18 m.y.B.P.), and corresponds to a major tectonic reorganization of sea-floor spreading on the Reykjanes Ridge (see Avery et al., 1969; Vogt and Avery, 1974); this change in spreading direction and increase in spreading rate resulted in the elimination of previously active transform faults. He suggests no strong causal relationship, except that the increase in spreading rate was somehow responsible for an increase in sediment input.

Studies of Hatton drift and Feni drift suggest that current-controlled morphology of these drifts began to develop as early as Oligocene (Ruddiman, 1972; Roberts, 1975). The results of drilling southwest of Rockall Plateau on DSDP Leg 48 have, however, led to the tentative conclusion that the flow of Norwegian Sea overflow water did not begin at Site 406 until Miocene (probably early/ middle Miocene) (Roberts and Montadert, in preparation). The older dates of Hatton and Feni drifts (Roberts, 1972; Laughton, Berggren, et al., 1972) were based on the age of sediments cored near the base of Sites 116 and 117. The results of Leg 48 (Roberts, Montadert, et al., in preparation) will be useful in determining whether drift development began before the Miocene influx of bottom water, or whether the "'Oligocene" reflector (Roberts's R4; Ruddiman's R) observed over much of the Rockall Plateau and Trough may represent an unconformity with much younger sediments beneath the sediment drifts.

The only additional site drilled under the inferred axis of the bottom current in the eastern North Atlantic is Site 114, which is too young to establish a date for initiation of flow. The high deposition rates suggest, however, that bottom currents have been influencing sedimentation at this site for most, if not all, of the past 5 million years.

\section{Regional Sedimentary Environment - Reykjanes Ridge Flank}

Sites 407 and 408 are situated on magnetic anomalies 13 and 6 , respectively, near $64^{\circ} \mathrm{N}$ on the west flank of Reykjanes Ridge (Figure 1). Sediments west of anomaly 5 show differential accumulation on a series of alternating hills and valleys with fairly steep walls, and they lack continuous reflectors (Figure 2). The basement is also blocky in this region; but the sediment thickness is not uniform, and bathymetric highs and lows are not strictly conformable with similar features in acoustic basement. Our interpretation is that the sediment distribution is controlled primarily by bottom current flow over an irregular bottom (elongated north-south by the spreading ridge), and that a complex deposition/erosion pattern has resulted from topographic influences.

Sediments recovered from Sites 407 and 408 strongly suggest that the difference in morphology between the eastern and western flanks of the Reykjanes Ridge at this latitude is a consequence of the difference in sediment supply to the bottom current. The smooth contours of the eastern flank result from the massive injection of Icelandic 
volcanogenic debris into a southward-flowing bottom current; no comparable sediment source exists on the west side to supply the northward-flowing near-bottom current. Thus, the influence of basement relief is apparent only in the region of relatively low sediment transport rates, and results in the irregular relief of the western ridge flank (Figure 2). We would infer that similar morphology was present on the east flank at earlier stages of sediment drift development.

\section{SEDIMENTATION AND EROSION BY BOTTOM CURRENTS: DRILLING DATA}

Four sites provide the principal control for the early/middle Miocene date of initiation of erosive bottom currents originating in the Norwegian Sea east of Iceland. They are Sites 336 (north flank of Iceland-Faroe Ridge), 352 (south flank of Iceland-Faroe Ridge), 406 (southwest of Rockall Plateau), and 407 (west flank of Reykjanes Ridge near $64^{\circ} \mathrm{N}$ ). An additional seven holes have been drilled at various sites in the northern North Atlantic, in regions which lie under the inferred path of Norwegian Sea overflow currents (Figure 3). All these sites show unconformities bracketing the date of the initiation of erosive flow, determined from the four sites mentioned above.

Iceland-Faroe Ridge: Sites $\mathbf{3 3 6}$ and $\mathbf{3 5 2}$

Sites 336 and 352 are on the northern and southern flanks (respectively) of the Iceland-Faroe Ridge. At both sites,

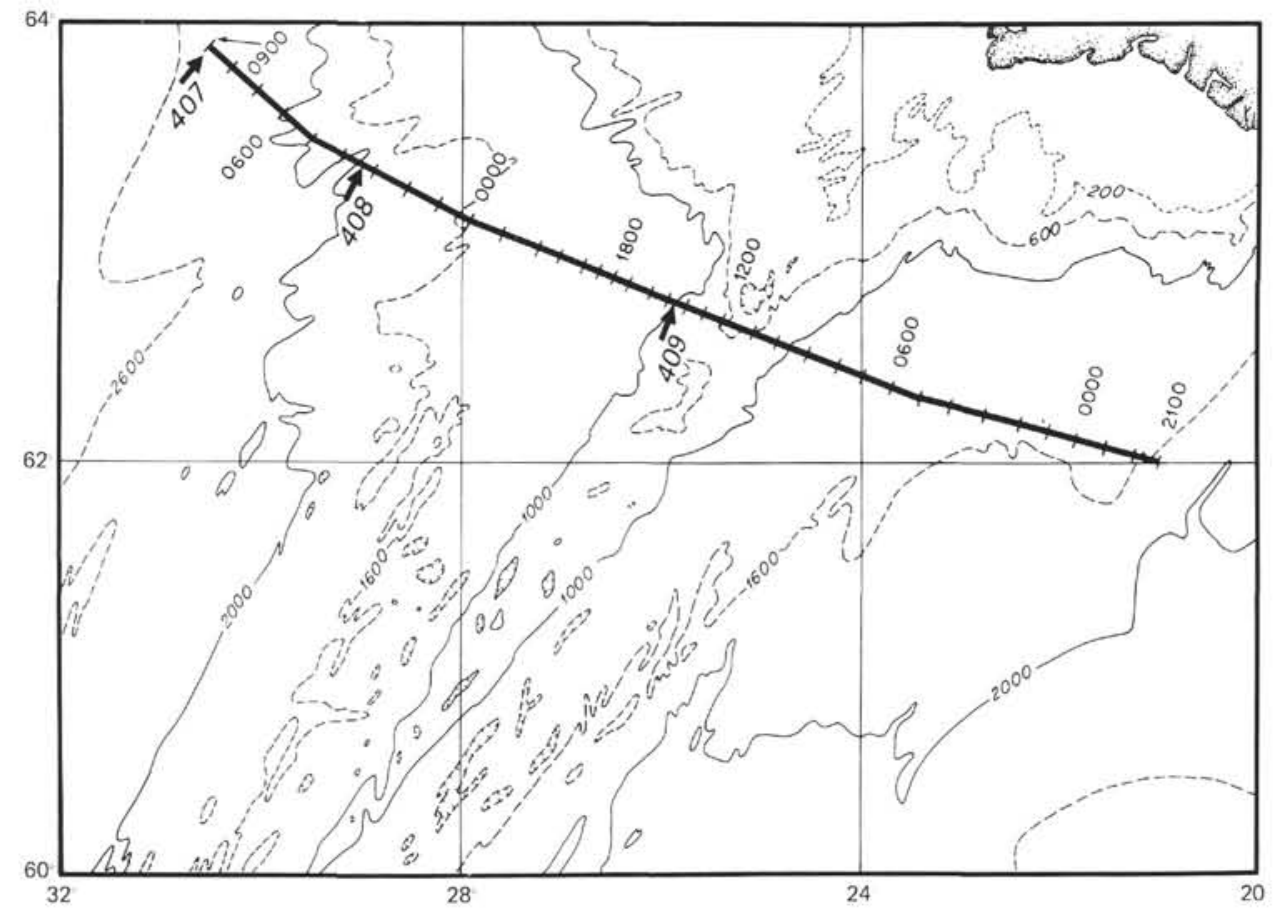

W

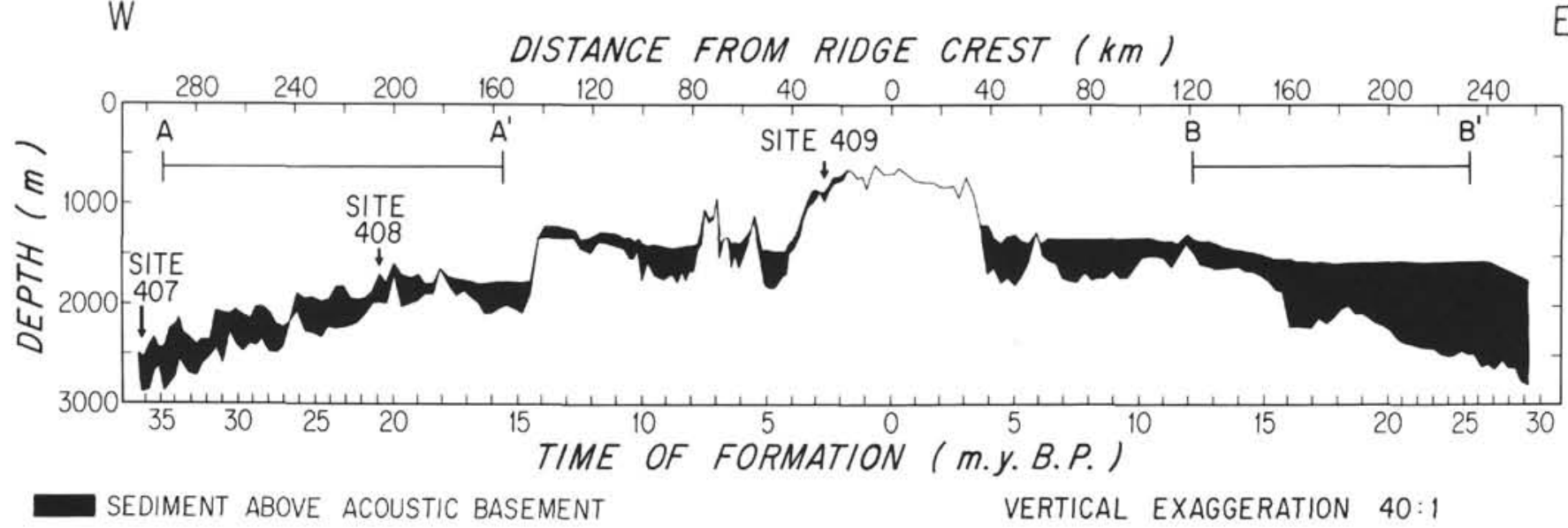

Figure 2. Interpreted seismic reflection section across Reykjanes Ridge between $62^{\circ}$ and $64^{\circ} \mathrm{N}$. (a) Track chart showing Glomar Challenger line. (b) Section showing water depth and depth to acoustic basement plotted against distance normal to Reykjanes Ridge strike. Sediment thickness assumes a constant velocity of $1.8 \mathrm{~km} / \mathrm{s}$. Age of formation is plotted using spreading rates discussed in text. (c) Details of airgun records on western $\left(A-A^{\prime}\right)$ and eastern (B-B') sides of Reykjanes Ridge. Note: airgun sections are reversed from interpreted section. 
glacial (upper Pliocene or Pleistocene) muds unconformably overlie upper Oligocene sediments (calcareous ooze at Site 352 , mud and clay [stone] at Site 336). The sediments are described in Talwani, Udintsev, et al. (1976) and Nilsen and Kerr (1978). The points important to the present study are as follows:

1) The lowermost sedimentary unit at Site 336 is a red unit of breccia to mudstone, interpreted as subaerially weathered basalt (Nilsen and Kerr, 1978).

2) Oligocene planktonic microfossil assemblages from the Norwegian Sea and the eastern North Atlantic are highly dissimilar, implying that no surface water connection existed between them before about $30 \mathrm{~m}$.y. ago (Schrader et al., 1976, p. 1205 [foraminifers], p. 1208 [radiolarians] and p. 1210 [diatoms]).

3) Water depths determined from the ratio of planktonic to benthic foraminifers at Site 336 indicate "inner-middle neritic" 45 m.y.B.P., gradually deepening to "outer neritic to upper bathyal"' 30 m.y.B.P. (Schrader et al., 1976).

Site 336 currently lies 800 meters below the sill depth of the Iceland-Faroe Ridge. An upper bathyal depth (200 to $600 \mathrm{~m}$ ) for this site $30 \mathrm{~m}$.y.B.P. suggests that most or all of the Iceland-Faroe Ridge was emergent, and certainly that no deep connection existed between the Norwegian Sea and the eastern North Atlantic.

The two Iceland-Faroe Ridge sites thus indicate that erosive bottom currents flowed no earlier than late Oligocene (about 25 m.y.B.P.). In addition, Site 336 has subaerially weathered "laterites"' overlying Eocene basalts which are now more than 1300 meters below sea level, strongly suggesting that the entire Iceland-Faroe Ridge lay above sea level at least through early Eocene time (K-Ar dates on the underlying basalts are $42 \pm 5$ m.y.B.P., according to Kharin et al., 1976). Both sites indicate
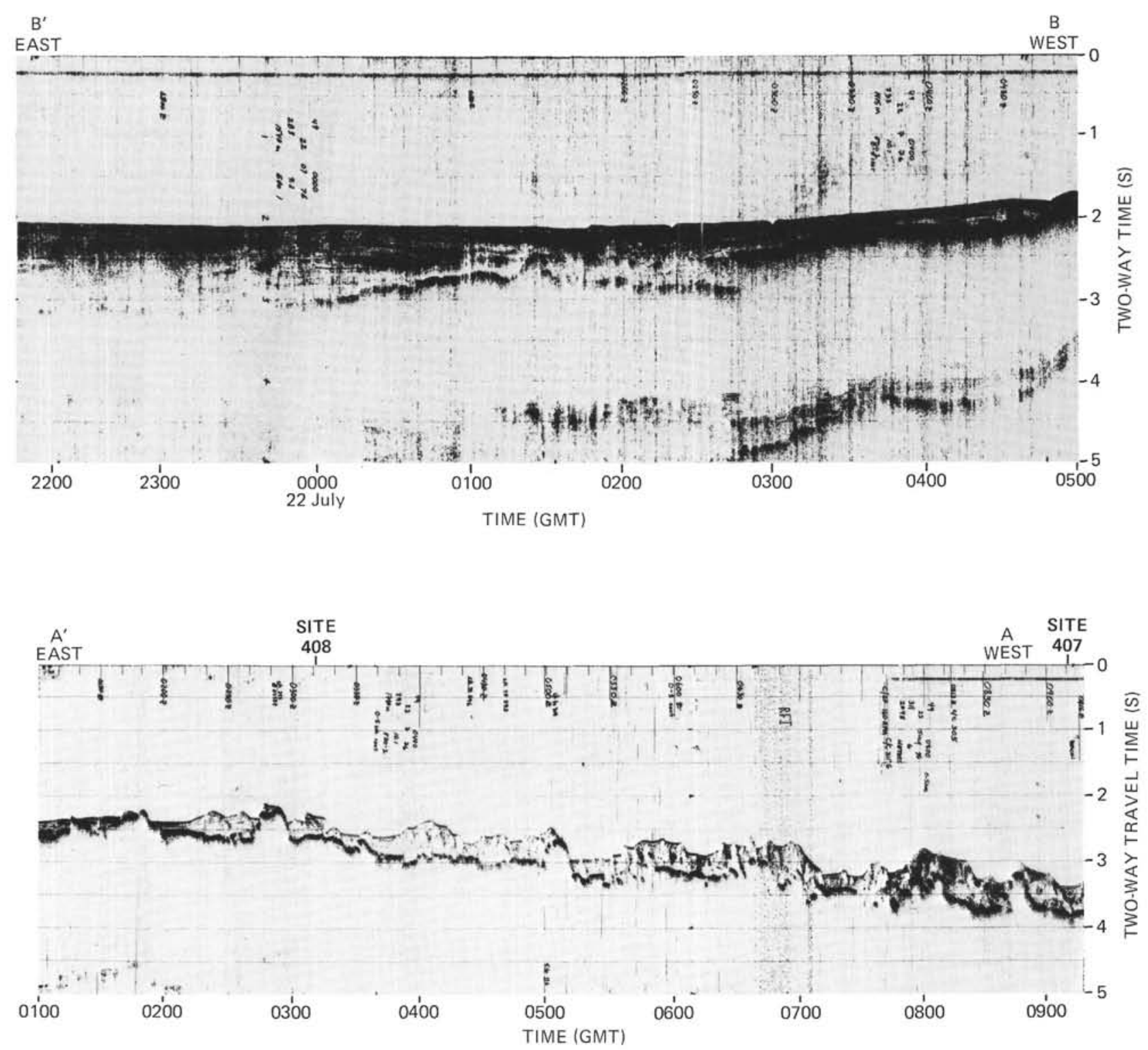

Figure 2. Continued. 


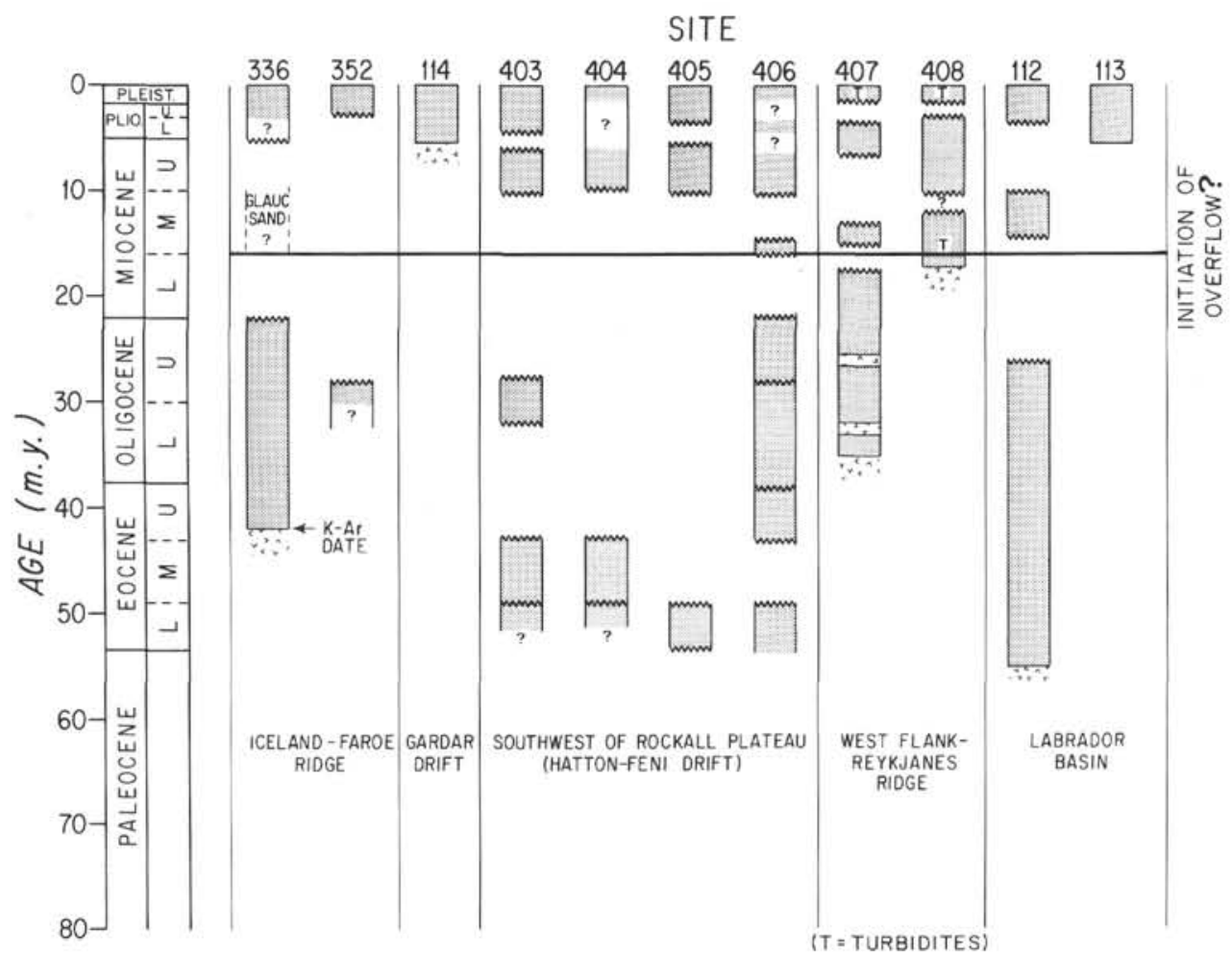

Figure 3. Age of Tertiary sediments recovered in northern North Atlantic DSDP sites inferred to lie under Norwegian Sea overflow current (see Figure 1 for locations). Ages of sediments from Leg 48 (Sites 403 through 406) are preliminary interpretations by shipboard scientists; other sites are published in Initial Reports volumes for Legs 12 and 38

essentially no deposition (or subsequent erosion) between the upper Oligocene marine deposits and the glacial muds. Site 336 yielded one core-catcher sample of glauconite sand, possibly middle Miocene, which could represent a brief period of non-erosion.

\section{Hatton Drift: Sites $\mathbf{4 0 3}$ through $\mathbf{4 0 6}$}

On Leg 48, four sites were drilled southwest of Rockall Plateau on the Hatton drift. Preliminary data show that Neogene unconformities occur at all these sites (Scientific Staff, Leg 48, 1976). The most detailed biostratigraphy is available for Site 406, where two Miocene unconformities appear to correlate with similar erosional horizons detected at Site 407. A 520-meter section of upper Miocene to Recent sediments unconformably overlies 80 meters of middle Miocene chalk and siliceous chalk. The estimated duration of the hiatus is from about 8 or 10 m.y.B.P. to 15 m.y.B.P. The relatively thin middle Miocene unit represents only a short period (probably about 2 million years), and is underlain unconformably by lower Miocene siliceous ooze. Additional hiatuses deeper in the hole separate Miocene and Oligocene, and Oligocene and Eocene material. The preliminary interpretation is that the middle/lower Miocene unconformity represents the initiation of strong bottom circulation, and records the beginning of sediment drift development in the eastern North Atlantic (Scientific Staff, Leg 48, 1976).

The three additional sites drilled near the southwest corner of Rockall Plateau all contain unconformities representing long periods between early Miocene and Eocene (with a short section of Oligocene material at Site 403). These findings are all compatible with an early/middle Miocene erosional event.

\section{West Flank of Reykjanes Ridge: Sites $\mathbf{4 0 7}$ and $\mathbf{4 0 8}$}

Site 407 lies under the inferred northward-flowing limb of the bottom current west of Reykjanes Ridge. Here again, a thick $(114 \mathrm{~m})$ upper Miocene to Pliocene sequence of nannofossil ooze and chalk unconformably overlies middle Miocene siliceous chalks (Figure 4). The middle Miocene sequence is quite short (about $25 \mathrm{~m}$ ), and is underlain unconformably by a continuous sequence of lower Miocene siliceous chalk which grades into upper Oligocene (about 22 to 26 m.y.B.P.) chalks and chalk-basalt breccia overlying basement. The basaltic basement at this site appears to represent a period (periods?) of off-axis volcanism, since older sediments are interlayered with the basalt. The oldest sediments recovered were cored at 101 meters sub-basement, and are lower Oligocene (about 30 to 35 m.y.B.P.). There is no compelling evidence for a hiatus within the lower Miocene sequence between the middle/lower Miocene unconformity and the top of the basalt. On the basis of the data discussed above, it appears that a widespread erosional event occurred near the middle/early Miocene boundary (Figure 3 ).

Site 408 contains a nearly continuous sequence of upper Miocene to Pliocene nannofossil ooze overlain unconformably by Pleistocene turbidites and glacial 


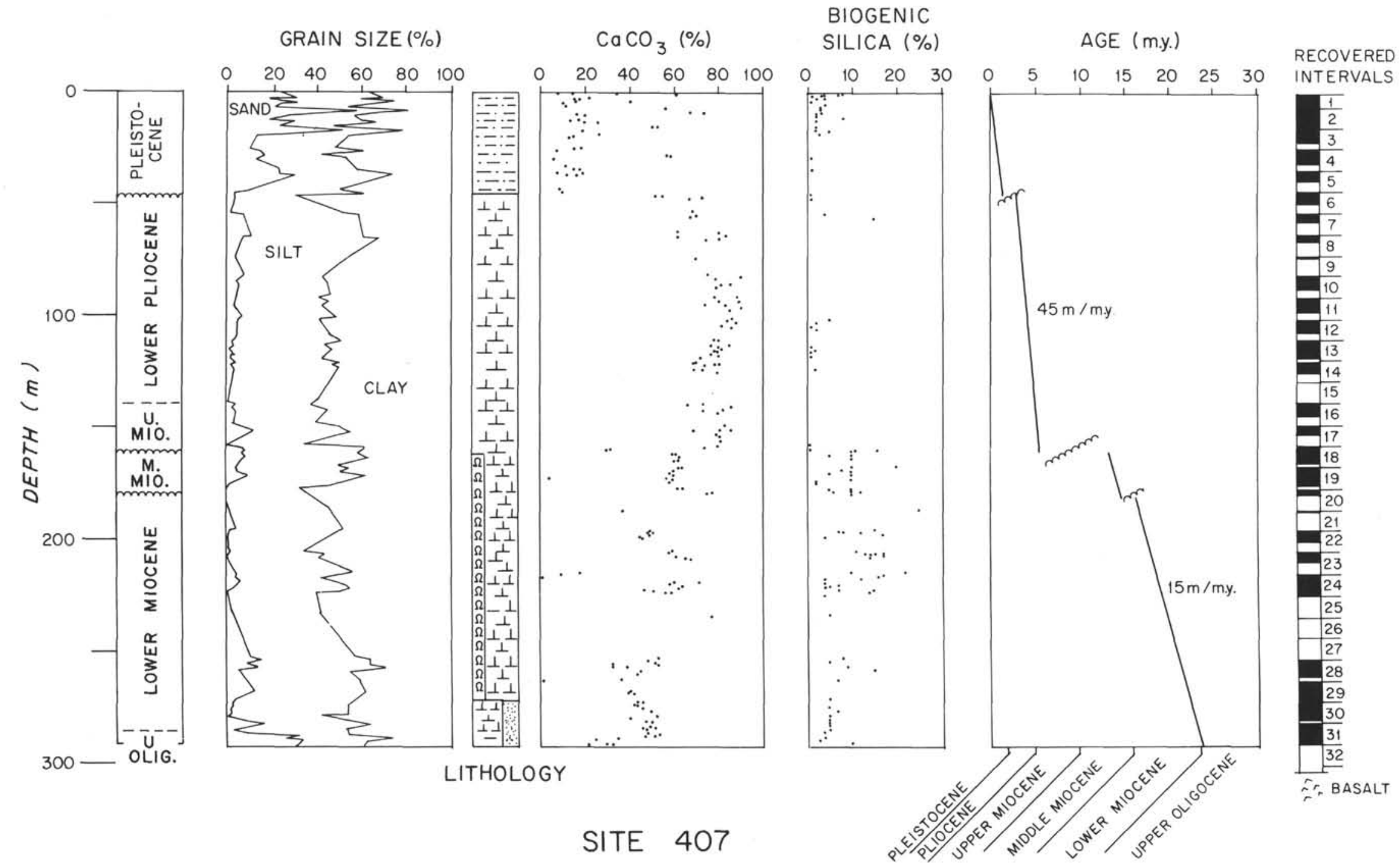

Figure 4. Selected components of Site 407 sediments, including age (nannofossil and foraminifer biostratigraphy); grain size (\% sand, silt, and clay performed by DSDP shore lab); per cent $\mathrm{CaCO}_{3}$ (DSDP shipboard and shore-lab analyses); biogenic silica (visual estimates by shipboard scientists), and recovered intervals. Hiatus between middle and upper Miocene is marked by a sharp decrease in biogenic silica in the younger sediments. Lithologic symbols as in Introduction. 
sediments, and underlain unconformably by middle to lower Miocene turbidites (Figure 5). The ooze contains scattered fine laminations of silt-sized material (principally glauconitized ash), suggesting bottom-current winnowing of silt. The lower section of middle and lower Miocene turbidites appears to be locally derived, as indicated by sharp, angular basalt sand and gravel, and the absence of shallow faunas. The basal sediments were deposited about $17 \mathrm{~m}$.y. ago, 2 to 4 million years after the estimated time when lithosphere at this site was formed. The upper turbidites probably derive from the Iceland margin, and apparently represent thick flows, since they occur perched on an abyssal hill and contain units more than a meter thick. They contain pelecypod fragments and other indicators of shallow deposition.

\section{MODELS OF RIDGE CREST ELEVATION THROUGH TIME}

Three principal factors should determine whether bottom water entering the eastern North Atlantic from the Norwegian Sea will be observed as a northward-flowing current on the west side of Reykjanes Ridge. They are (1) the depth of Reykjanes Ridge relative to the basins on either side, (2) the distribution and depth of fracture zones cutting the ridge, and (3) the density of water entering the Atlantic from the Norwegian Sea relative to the density of the deep water in the two basins. We summarize below the information from Luyendyk, Shor, and Cann (this volume) concerning two possible models of Reykjanes Ridge crest depth through time, both of which appear compatible with the available data. We then discuss in the following section the consequences of ridge elevation changes on the circulation of bottom currents between the eastern and western basins.

1) The "steady-state" model. This model estimates the initial ridge crest elevation at any age, $t$, by backtracking the depth of $\mathrm{t}$-age crust along a $\mathrm{z}=350(\mathrm{t})^{1 / 2}$ curve, as discussed in Parsons and Sclater (1977). Spreading rates of $1.0 \mathrm{~cm} /$ year $(0$ to $200 \mathrm{~km})$ and $0.625 \mathrm{~cm} /$ year $(>200 \mathrm{~km})$ were used to convert distance from the ridge axis into crustal age (see Luyendyk, Shor, and Cann, this volume). Excess subsidence caused by sediment loading is removed by assuming isostatic adjustment of the lithosphere to a regression line fitted independently to sediment thickness data for each side of the ridge.

The resulting time series of initial crest depths is illustrated in Figure 6. If this model is valid, then several conclusions may be drawn. First, before 17 m.y.B.P., the crest depth was approximately constant at about 500 meters following which a tectonic, volcanic, or thermal event elevated the ridge crest to near sea level. The ridge crest then gradually subsided to nearly 1000 meters 4 m.y.B.P. and a second shallowing episode again brought the crest to less than $\mathbf{5 0 0}$ meters, from which it is now subsiding.

The evidence supporting this model is that depths determined both from vesicularity of basalt samples and from benthic foraminiferal assemblages at the bases of Sites 407,408 , and 409 are compatible with the depths estimated by backtracking the depths of these sites to the age of the oldest sediment (not the age of the lithosphere) (Luyendyk, Shor, and Cann, this volume). If the recovered basalts were erupted at Sites 407 and 408 somewhat later than the magnetic age of the crust, then this model suggests that the Reykjanes Ridge can be considered in terms of a "steady-state", spreading model, and has had a shallow elevation since before 36 m.y. ago.

2) Uplift models. Several possible models of ridge crest elevation which satisfy our data add to the model above a component of uplift for a specified period. One alternative is similar to that of Duffield (this volume), in which the ridge crest is assumed to have shallowed at a constant rate since 36 m.y.B.P. An average uplift rate since crustal formation at any site can be estimated by assuming that the basal sediments were deposited shortly after crustal formation. We can then use the depths estimated from benthic foraminiferal assemblages to estimate eruption depth $\left(D_{e}\right)$ in the following equation (from Duffield, this volume):

$$
\mathrm{D}_{\mathrm{p}}^{*}=\mathrm{D}_{\mathrm{e}}+\mathrm{C}-\mathrm{U} ; \mathrm{U}=\mathrm{t} \times \mathrm{r}
$$

$$
\begin{aligned}
\text { where } & \\
\mathrm{D}_{\mathrm{p}}^{*}= & \text { present basement depth in meters (corrected } \\
& \text { for sediment loading) } \\
\mathrm{D}_{\mathrm{e}}= & \text { eruption depth in meters (initial ridge crest } \\
& \text { depth) } \\
\mathrm{C}= & \text { subsidence }(\mathrm{in} \mathrm{m}) \text { resulting from cooling } \\
& {\left[\mathrm{C}=350(\mathrm{t})^{1 / 2}\right] } \\
\mathrm{U}= & \text { uplift }(\text { in } \mathrm{m}) \\
\mathrm{t}= & \text { age of crust }(\mathrm{m} . \mathrm{y} .) \\
\mathrm{r}= & \text { uplift rate }(\mathrm{m} / \mathrm{m} . \mathrm{y} .)
\end{aligned}
$$

All variables are thus known except the uplift rates (Table 1). The maximum rate compatible with the data is about 25 $\mathrm{m} / \mathrm{m}$.y. (see Luyendyk, Shor and Cann, this volume, for a slightly different method).

The depths determined in this manner do not agree with the depths estimated by the Moore and Schilling (1973) vesicularity versus depth relation (Figure 7), but the general relationship of decreasing vesicularity with increasing water depth holds. Possible explanations, including different techniques, are discussed in Duffield (this volume).

\section{RIDGE ELEVATION CHANGES AND BOTTOM CURRENT FLOW}

The common feature of the two models discussed above is a marked change in ridge crest elevation (outer escarpment) between 15 and 17 m.y.B.P., following which the ridge appears to have remained anomalously shallow for about 5 million years (Figure 6). This escarpment appears on all profiles taken across the northern Reykjanes Ridge (e.g., Talwani et al., 1971; Vogt and Avery, 1974). We believe that the age of this escarpment correlates with the first erosional episodes that can be confidently ascribed to the flow of bottom water into the eastern North Atlantic from the Norwegian Sea, and with the age of the oldest turbidites deposited at Site 408. In addition, it may be significant that $17 \mathrm{~m} . \mathrm{y}$. is the age of the oldest dated basalts that are subaerially exposed on Iceland (Moorbath et al., 1968), and may date a major elevation of the Icelandic basalt pile. We infer that a major tectonic change at about the early/middle Miocene boundary resulted in uplift of the entire northern Reykjanes Ridge crest, either by extrusion of 


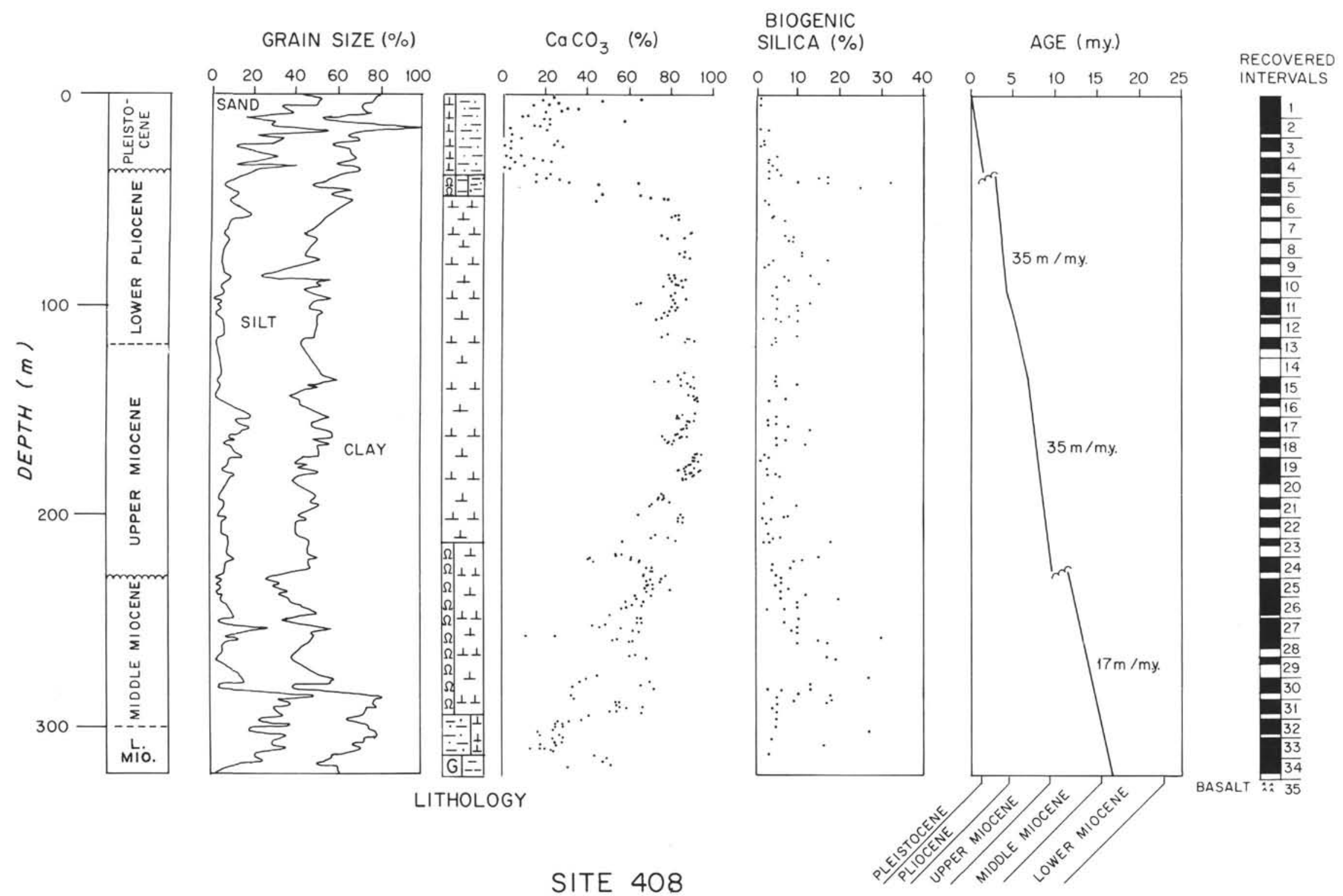

Figure 5. Selected components of Site 408 sediments (see Figure 4). Middle Miocene sediments again show higher proportion of biogenic silica than overlying deposit. 


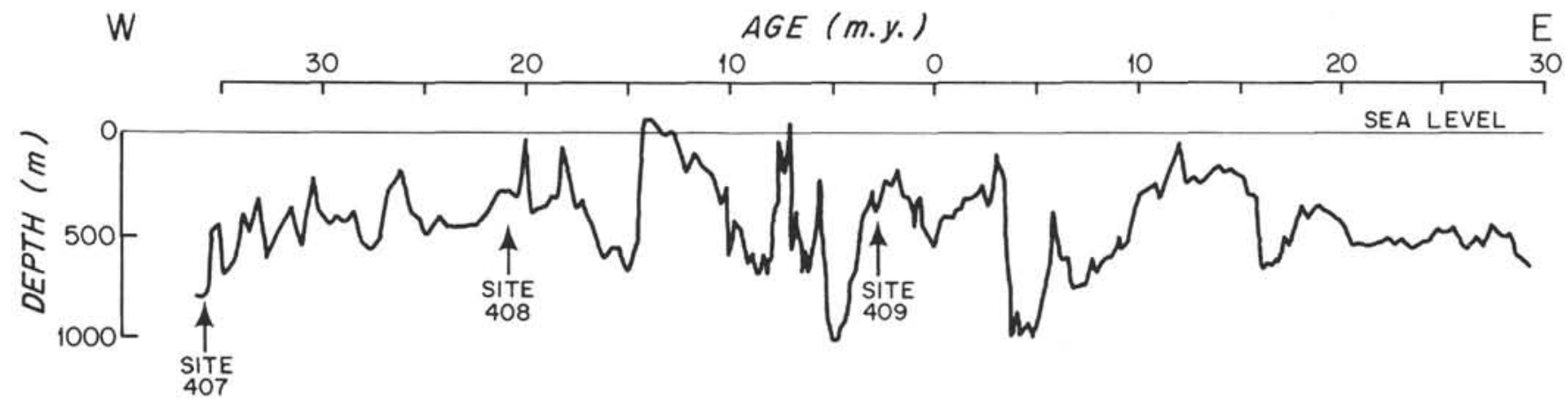

Ridge Crest Elevation vs. Age

Figure 6. Time series of initial ridge crest depths, calculated by backtracking basement depths in Figure 2 along subsidence relationship $\Delta_{z}=350 \sqrt{\mathrm{t}}$ (Parsons and Sclater, 1977). Basement depths are corrected for excess sediment loading.

TABLE 1

Values Used to Calculate Uplift Rate of Reykjanes Ridge, Following Method of Duffield (this volume)

\begin{tabular}{|c|c|c|c|}
\hline & Site 407 & Site 408 & Site 409 \\
\hline Age $(t)$ & 36 m.y. & 20.9 m.y. & 2.7 m.y. \\
\hline $\begin{array}{l}\text { Subsidence resulting from } \\
\text { lithospheric cooling (C) }\end{array}$ & $2100 \mathrm{~m}$ & $1600 \mathrm{~m}$ & $575 \mathrm{~m}$ \\
\hline Present water depth $\left(D_{p}\right)$ & $2896 \mathrm{~m}$ & $1946 \mathrm{~m}$ & $912 \mathrm{~m}$ \\
\hline $\begin{array}{l}\text { Sediment loading } \\
\text { increase }\left(D_{s}\right)\end{array}$ & $99 \mathrm{~m}$ & $76 \mathrm{~m}$ & 0 \\
\hline $\begin{array}{l}\text { Corrected basement depth } \\
\left(D_{\mathrm{p}}^{*}=\mathrm{D}_{\mathrm{p}}-\mathrm{D}_{\mathrm{s}}\right)\end{array}$ & $2797 \mathrm{~m}$ & $1870 \mathrm{~m}$ & $912 \mathrm{~m}$ \\
\hline $\begin{array}{l}\text { Eruption depth }\left(\mathrm{D}_{\mathrm{e}}\right) \\
\text { a) Faunal } \\
\text { b) Vesicles }\end{array}$ & $\begin{aligned} 1500 & \neq 500 \mathrm{~m} \\
940 & \neq 240\end{aligned}$ & $\begin{aligned} 1000 & \pm 200 \mathrm{~m} \\
530 & \pm 240\end{aligned}$ & $\begin{array}{l}400 \pm 200 \mathrm{~m} \\
210 \pm 240\end{array}$ \\
\hline $\begin{array}{l}\text { Calculated uplift rate (r) } \\
\text { a) Faunal } \\
\text { b) Vesicles }\end{array}$ & $\begin{array}{l}22 \pm 14 \mathrm{~m} / \mathrm{m} \cdot \mathrm{y} . \\
7 \pm 6\end{array}$ & $\begin{array}{l}35 \pm 10 \mathrm{~m} / \mathrm{m}, \mathrm{y} . \\
12 \pm 12\end{array}$ & $\begin{aligned} 23 & \pm 70 \mathrm{~m} / \mathrm{m} . \mathrm{y} . \\
-47 & \pm 90\end{aligned}$ \\
\hline $\begin{array}{l}\text { Note: Age }(t) \text { is derived fro } \\
\text { by cooling }(\mathrm{C}) \text { from } \mathrm{P} \\
\text { depth to basement (lov } \\
0.3 \text { times sediment thic } \\
\text { from ridge axis for each } \\
\text { thic foraminifers and } \mathrm{v} \\
\text { ridge crest. Positive sign }\end{array}$ & $\begin{array}{l}\text { m distance from } \\
\text { rsons and Sclater } \\
\text { ver basalt unit for } \\
\text { kness (from linea } \\
\text { side of ridge); eru } \\
\text { esicularity of bas } \\
\text { for } r \text { implies uplif }\end{array}$ & $\begin{array}{l}\text { idge axis (see Fig } \\
1977 \text {; water dep } \\
\text { Site } 407 \text { ); sedime } \\
\text { regression of dep } \\
\text { tion depths are e } \\
\text { Its (see text), ass }\end{array}$ & $\begin{array}{l}\text { Ire } 2) \text {; subsidence } \\
\text { th }\left(D_{p}\right) \text { is drilled } \\
\text { t loading }\left(D_{s}\right) \text { is } \\
\text { h versus distance } \\
\text { imates from ben- } \\
\text { ming eruption at }\end{array}$ \\
\hline
\end{tabular}

excess volcanic magma or by tectonic readjustment to a new (faster) spreading regime.

Assuming this inference to be correct, then it is reasonable to carry the argument one step further and suggest that the shallowing of the ridge crest and the correlative elimination of most or all of the major transform faults cutting the ridge (Avery et al., 1969; Vogt and Avery, 1974; Ruddiman, 1972) resulted in confinement of the inflowing Norwegian Sea water to the eastern basin in the north, in which case it thus did not flow directly across the ridge through the fractures. This may have led to more widespread erosion by a larger and possibly stronger flow which was pushed far to the south before it could cross the ridge. Ruddiman's (1972) observations of asymmetric and rapid fill of the fracture zones above an acoustic reflector dated about 17 m.y.B.P. agree with this interpretation; with no exit across the ridge, the fracture zones would act as sediment traps.

The subsequent history of the bottom flow is more difficult to interpret, since only two of the sites drilled under

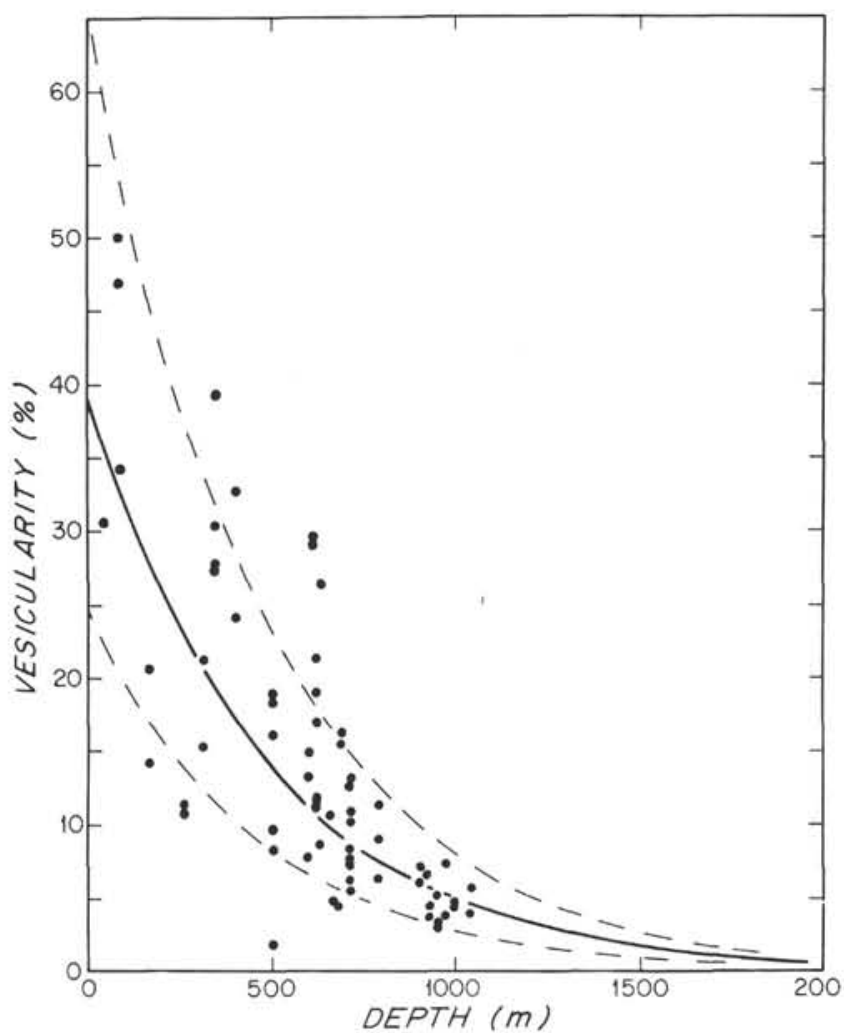

Figure 7. Vesicularity (\%) versus recovery depth (m) of Reykjanes Ridge basalts analyzed by Moore and Schilling (1973). Data are fit with exponential curve $V=40 e$. $.002085 z$ with $r=0.73$. Standard deviation of observed versus calculated depths is 240 meters. Leg 49 samples were selected to obtain samples with maximum vesicularity (see Duffield, this volume), and so are expected to provide minimum depth estimates for each site.

the inferred path of the flow contain any middle Miocene deposits. It is possible that the intensity of flow decreased briefly during the middle Miocene, resulting in the deposition observed at Sites 407 and 406; but it is also possible that these deposits represent accumulations protected from the main axis of the current. This may 
explain the problems in correlating the nannofossil and foraminifer biostratigraphies for the middle Miocene section at Site 407: lower Miocene material may have been reworked into these cores (see Poore et al., this volume).

It appears that erosion dominated in the middle Miocene along the current path (perhaps redepositing material to shape the sediment drifts), and that renewed accumulation did not begin until the late Miocene, when widespread deposition again occurred. This may be explained by the deepening of the ridge crest after 10 m.y.B.P. (Figure 6) and by the resultant increase in cross-ridge flow in the north and decrease in volume and velocity of the along-ridge flow. Deposition apparently continued into the early Pliocene. There is some evidence for a renewed period of erosion beginning during the Pliocene; this may correlate with the age of the inner escarpment (Figure 2). No glacial Pliocene material ( 2 to 3 m.y.B.P.) was recovered at either Site 407 or Site 408 , although both sites are certainly within the region where ice rafting should be represented in the upper Pliocene. We suspect, therefore, that erosion occurred between deposition of the lower Pliocene nannofossil ooze and the Pleistocene turbidites and ice-rafted deposits at both sites.

\section{SUMMARY OF NEOGENE CIRCULATION AND RELATED EVENTS}

We present below a brief summary of events leading to the modern deep circulation in the eastern North Atlantic and across the Reykjanes Ridge. It must be considered tentative until problems with the interpretation of the elevation of Reykjanes Ridge through time can be resolved.

Middle to late Oligocene ( 25 to 30 m.y.B.P.): Initial establishment of a surface connection between the eastern North Atlantic and Norwegian Sea occurred.

Late Oligocene to early Miocene (20 to 25 m.y.B.P.): The deep connection between the eastern North Atlantic and the Norwegian Sea was established. The first bottom water flow probably began through Rockall Trough and across the Iceland-Faroe Ridge at about the same time, judging by the apparent similarity in age of the Hatton and Gardar drifts.

Early to middle Miocene (15 to 17 m.y.B.P.): A major tectonic reorganization of sea-floor spreading occurred, eliminating the previous deep fracture zones which cut across the ridge (Vogt and Avery, 1974) and leading to shallowing of the ridge crest and possibly a major buildup of the Icelandic basalt pile. Correlation of erosional events at Site 407 and 406 suggests a widespread increase in bottom flow velocity.

Late Miocene (6 to 8 m.y.B.P.): Renewed deposition began at all sites drilled along the path of the overflow current in the eastern North Atlantic (403, 404, 405, 406, $114)$, as well as at sites west of the ridge axis $(407,408)$. The only sites showing no deposition are those on the Iceland-Faroe Ridge $(336,352)$. This renewal of deposition may correlate with the increasing depth of the Reykjanes Ridge crest, beginning about 10 m.y.B.P. and reaching a maximum 4 to 5 m.y.B.P.

Pliocene (3 to 5 m.y.B.P.): Uplift of the ridge crest apparently occurred about 4 m.y.B.P., which may correlate with the early Pliocene to Pleistocene unconformity at Sites
407 and 408. This suggests an increase in current activity corresponding to shallowing of the ridge, similar to that in the early/middle Miocene.

Pleistocene to Recent: This section is overprinted at both Sites 407 and 408 by turbidites (probably from the Iceland margin) and by ice-rafted detritus, making it impossible to determine whether bottom currents were erosive during the past two million years.

\section{PLIOCENE ICE RAFTING IN THE NORTH ATLANTIC}

One additional significant finding of DSDP Leg 49 was the ice-rafted mineral grains in upper Pliocene sediments of Hole 410. This corroborates the Pliocene glaciation noted during DSDP Leg 12, and indicates that icebergs penetrated at least as far south as $45^{\circ} \mathrm{N}$ during the late Pliocene. A correlative decrease in $\mathrm{CaCO}_{3}$ is evident, and implies changes in sediment sources, probably increased influx of fine terrigenous material (Figure 8). Our data, combined with the results of DSDP Legs 12 and 37, allow estimation of the southern extent of late Pliocene ice rafting in the North Atlantic (Figure 9). Because ice-rafted mineral grains in samples examined for foraminifers are sparse to few in the upper Pliocene, and because larger glacial erratics are absent altogether, we place the southern limit close to Hole 410 rather than halfway between Hole 410 and Holes 333 and 335 .

The lowest occurrence of ice-rafted mineral grains ( $\geqslant 63$ $\mu \mathrm{m}$ ) in Sample 15, CC of Hole 410 corresponds to the first evolutionary occurrence of Globorotalia inflata (d'Orbigny). The first evolutionary occurrence of Globorotalia inflata approximates the base of upper Pliocene Zone N21, and has an estimated age of 3.0 m.y. (Poore and Berggren, 1974). Thus, the first (lowest) occurrence of ice-rafted mineral grains at Site 410 agrees closely with the estimated date of 3.0 m.y.B.P. for extensive Northern Hemisphere glaciation determined by Berggren (1972) and the paleomagnetically controlled isotopic evidence for initiation of significant Northern Hemisphere glaciation 3.2 m.y. ago (Shackleton and Opdyke, 1977).

Although control points are few, data plotted in Figure 8 indicate that the ice-rafted component of Cores 1 through 7 is greater than in Cores 8 through 15. Assuming a constant sediment accumulation rate for the upper portion of Hole 410 indicates an age of 1.1 to $1.2 \mathrm{~m} . \mathrm{y}$. for the base of Core 7 (recovered interval). Since an increase in the ice-rafted component of sediments from this area of the North Atlantic reflects glacial conditions on land (Ruddiman, 1977), our data suggest an increase in the magnitude and frequency of Northern Hemisphere glaciation at about this time.

A detailed study of several North Pacific cores by Kent et al. (1971) revealed a significant up-section increase of ice-rafted material at the level representing 1.2 m.y.B.P. Thus, the pattern of increased influx of ice-rafted material to North Pacific sediments 1.2 m.y. ago, which Kent et al. (1971) attribute to increased glaciation in the Cordilleran region of North America and the Kamchatka Peninsula, and tentatively correlate with the initiation of mid-latitude glaciation in the Northern Hemisphere, is apparently present in the temperate regions of the North Atlantic as well. 


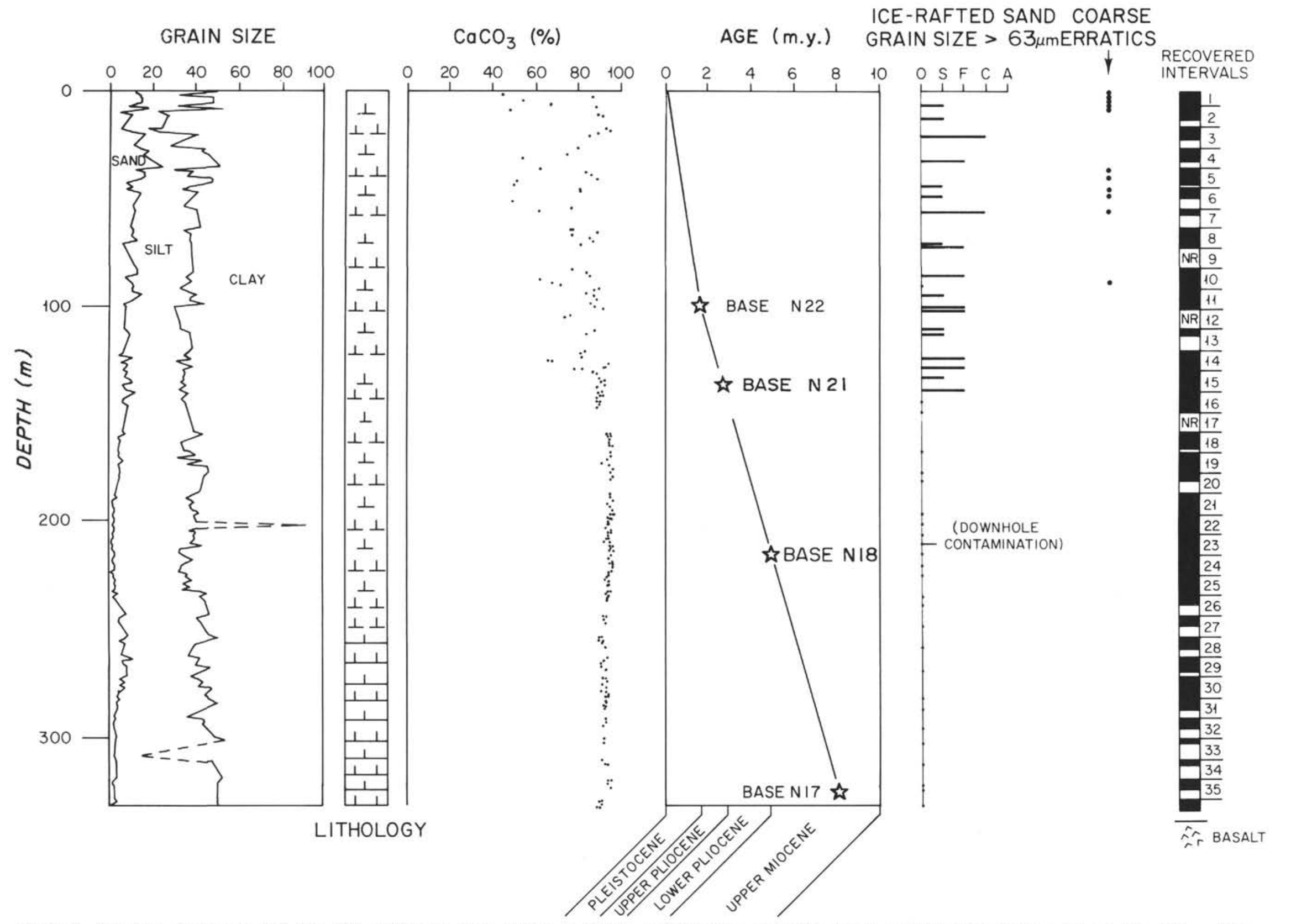

Figure 8. Selected components of Site 410 sediments. Note change in $\mathrm{CaCO}_{3}$ and presence of sand grains in samples younger than foraminiferal Zone N21 ( 3 m.y.B.P.), indicating influx of terrigenous material by icebergs. Larger erratics did not become abundant until about 1 m.y.B.P. Frequency of ice-rafted grains in samples examined for foraminifers: $0=$ zero $;=$ some; $F=$ few; $C=$ common; $A=$ abundant. 


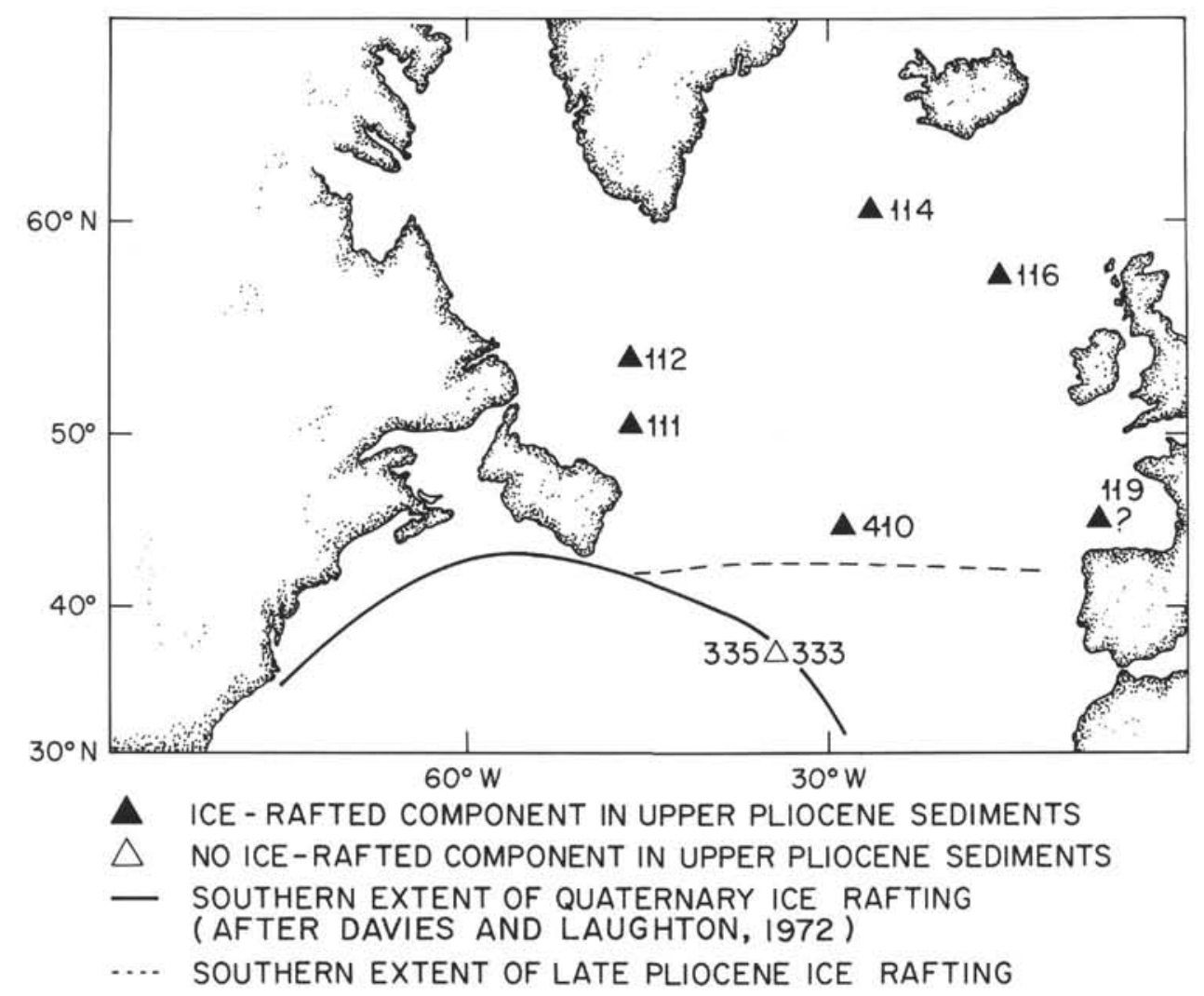

Figure 9. Distribution of Pliocene ice-rafted grains in North Atlantic DSDP sites, showing estimated maximum southward penetration of Pliocene icebergs. Modified after Davies and Laughton, 1972.

\section{ACKNOWLEDGMENTS}

We are grateful to Wendell Duffield and Bruce Luyendyk for assistance with interpreting various aspects of the tectonic history of the Reykjanes Ridge, and to W. Berggren, C. Hollister, D. Johnson, J. Gardner, and C. Repenning, who reviewed an earlier version of the manuscript. We also thank David Roberts for valuable discussions of the preliminary results of Leg 48 . The technical support of the DSDP technicians and Global Marine personnel under extremely difficult circumstances during Leg 49 was greatly appreciated.

\section{REFERENCES}

Avery, O.E., Vogt, P.R., and Higgs, R.H., 1969. Morphology, magnetic anomalies and evolution of the northeast Atlantic and Labrador Sea, pt. II. Magnetic anomalies, EOS Am. Geophys. Union Trans., v. 50, p. 184.

Berggren, W.A., 1972. Late Pliocene-Pleistocene glaciation. In Laughton, A.S., Berggren, W.A., et al., Initial Reports of the Deep Sea Drilling Project, v. 12: Washington (U.S. Government Printing Office), p. 953-963.

Berggren, W.A., and Hollister, C.D., 1974. Paleogeography, paleobiogeography and the history of circulation in the Atlantic Ocean. In Hay, W. (Ed.), Studies in paleo-oceanography: S.E.P.M. Special Publication 20, p. 126-186.

, 1977. Plate tectonics and paleocirculation commotion in the ocean, Tectonophysics, v. 38, p. 11-48.

Crease, J., 1965. The flow of Norwegian Sea water through the Faroe Bank Channel, Deep-Sea Research, v. 12, p. 143-150.

Davies, T.A., and Laughton, A.S., 1972. Sedimentary processes in the North Atlantic. In Laughton, A.S., Berggren, W.A., et al., Initial Reports of the Deep Sea Drilling Project, v. 12: Washington (U.S. Government Printing Office), p. 905-934.

Ewing, J.I., and Hollister, C.D., 1972. Regional aspects of deep sea driling in the western north Atlantic. In Hollister, C.D., Ewing, J.I., et al., Initial Reports of the Deep Sea Drilling Project, v. 11: Washington (U.S. Government Printing Office), p. $951-973$.

Fuglister, F.C., 1960. Atlantic Ocean Atlas, Volume 1. Woods Hole Oceanographic Institution, Woods Hole, Massachusetts.

Garner, D.M., 1972. Flow through the Charlie-Gibbs Fracture Zone, Mid-Atlantic Ridge, Canadian Journal of Earth Sciences, v. 9, p. 116-121.

Hollister, C.D., Flood, R., and McCavz, I.N., 1978. Plastering and decorating in the NorthAtlantic. Oceanus, v. 21, p.5-13.

Johnson, G.L., and Schneider, E.D., 1969. Depositional ridges in the North Atlantic, Earth and Planetary Sciences Letters, v. 6, p. 416-422.

Johnson, G.L., Vogt, P.R., and Schneider, E.D., 1971. Morphology of the Northeastern Atlantic and Labrador Sea, Deutsche Hydrographische Zeitschrift, v. 24, p. 49-73.

Jones, E.J.W., Ewing, M., Ewing., J.I., and Eittreim, S.L., 1970. Influences of Norwegian Sea overflow water on sedimentation in the northern North Atlantic and Labrador Sea, Journal of Geophysical Research, v. 75, p. 1655-1680.

Kellogg, T.B., 1976. Late Quaternary climatic changes: evidence from deep-sea cores of Norwegian and Greenland Seas. In Cline, R.M., and Hays, J.D. (Eds.), Investigation of late quaternary paleo-oceanography and paleoclimatology: G.S.A. Memoir 145, p. 77-110.

, 1977. Paleoclimatology and paleo-oceanography of the Norwegian and Greenland Seas: the last 450,000 years, Marine Micropaleontology, v. 2, p. 235-249. 
Kent, D., Opdyke, N.D., and Ewing, M., 1971. Climate change in the North Pacific using ice-rafted detritus as a climatic indicator, Bulletin of the Geological Society of America, v. 82, p. 2741-2754.

Kharin, G.N., Udintsev, G.B., Bogatikov, O.A., Dmitriev, J.I., Raschka, H., Kreuzer, H., Mohr, M., Harre, W., and Eckhardt, F.-J., 1976. K/Ar age of the basalts of the Norwegian-Greenland Sea, DSDP Leg 38. In Talwani, M., Udintsev, G., et al., Initial Reports of the Deep Sea Drilling Project, v. 38: Washington (U.S. Government Printing Office), p. 755-760.

Laughton, A.S., Berggren, W.A., et al., 1972. Initial Reports of the Deep Sea Drilling Project, v.12: Washington (U.S. Government Printing Office).

LePichon, X., Eittreim, S.L., and Ewing, J.I., 1971. A sedimentary channel along Gibbs Fracture Zone, Journal of Geophysical Research, v. 76, p. 2891-2896.

McKenna, M.C., 1972. Eocene final separation of the Eurasian and Greenland-North American land masses, 24th International Geological Congress (Section 7), p. 275-281.

, 1975. Fossil mammals and Early Eocene North Atlantic land continuity, Annals of the Missouri Botanical Garden, v. 62, p. 335-353.

Moorbath, S., Sigurdsson, H., and Goodwin, R., 1968. K-Ar ages of the oldest exposed rocks in Iceland, Earth and Planetary Science Letters, v. 4, p. 197-205.

Moore, J.G., and Schilling, J-G., 1973. Vesicles, water and sulfur in Reykjanes Ridge basalts, Contributions in Mineralogy and Petrology, v.41, p. 105-118.

Nilsen, T.H., and Kerr, D.R., 1978. Paleoclimatic and paleogeographic implications of a lower Tertiary laterite (latosol) on the Iceland-Faeroe Ridge, North Atlantic region, Geological Magazine, v. 115.

Parsons, B., and Sclater, J.G., 1977. An analysis of the variation of ocean floor bathymetry and heat flow with age, Journal of Geophysical Research, v. 82, p. 803-827.

Poore, R.Z., and Berggren, W.A., 1974. Pliocene biostratigraphy of the Labrador Sea: Calcareous plankton, Journal of Foraminiferal Research, v. 5, p. 270-293.

Reid, J.L., 1977. Circulation of the Mediterranean Water in the North Atlantic Ocean (abstract), EOS Transactions of the American Geophysical Union, v. 58, p. 1168.

Roberts, D.G., 1975. Marine geology of the Rockall Plateau and Trough, Philosophical Transactions of the Royal Society of London, ser. A, v. 278 , p. 447-509.

Ruddiman, W.F., 1972. Sediment redistribution on the Reykjanes Ridge: seismic evidence, Bulletin of the Geological Society of America, v. 83, p. 2039-2062. 1977. North Atlantic ice-rafting: a major change at 75,000 before the present, Science, v. 196, p. 1208-1211.
Schrader, J-J., Bjørklund, K., Manum, S., and van Hinte, J., 1976. Cenozoic biostratigraphy, physical stratigraphy and paleo-oceanography in the Norwegian-Greenland Sea, DSDP Leg 38 paleontological synthesis. In Talwani, M., Udintsev, G., et al., Initial Reports of the Deep Sea Drilling Project, v. 38, p. 1197-1211.

Scientific Staff, DSDP, Leg 48, 1976. Glomar Challenger sails on Leg 48, Geotimes, v. 21, p. 19-23.

Shackleton, N.J., and Opdyke, N.D., 1977. Oxygen isotope and paleomagnetic evidence for early Northern Hemisphere glaciation, Nature, v. 270 , p. 216-219.

Shor, A.N., 1977. Transport of Norwegian Sea Overflow preliminary results of Atlantis II Cruise 94, June-July 1977, International Council for the Exploration of the Sea (unpublished manuscript CM 1977/c:44).

Steele, J.H., Barrett, J.R., and Worthington, L.V., 1962. Deep currents south of Iceland, Deep-Sea Research, v.9, p. 465-474.

Tait, J.B. (Ed.), 1967. The Iceland-Faroe Ridge International (ICES) “'Overflow"' Expedition, May-June, 1960, Rapports et Proces-Verbaux des Reunions, v. 157, p. 274.

Talwani, M., Udintsev, G., et al., 1976. Initial Reports of the Deep Sea Drilling Project, v. 38: Washington (U.S. Government Printing Office).

Talwani, M., Windisch, C.C., and Langseth, M.G., Jr. 1971. Reykjanes Ridge crest: a detailed geophysical study, Journal of Geophysical Research, v. 76, p. 473-517.

Tucholke, B.E., 1978. Relationships between acoustic stratigraphy and lithostratigraphy in the western North Atlantic Basin. In Tucholke, B.E., Vogt, P., et al., Initial Reports of the Deep Sea Drilling Project, v.43: Washington (U.S. Government Printing Office).

Vogt, P.R., 1972. The Faeroe-Iceland-Greenland aseismic ridge and the Western Boundary Undercurrent, Nature, v. 239, p. 79-81.

Vogt, P.R., and Avery, O.E., 1974. Detailed magnetic surveys in the Northeast Atlantic and Labrador Sea, Journal of Geophysical Research, v.79, p. 363-389.

Weyl, P.K., 1968. The role of the oceans in climatic change: a theory of the ice ages. In Mitchell, J.M. (Ed.), Causes of climatic change (Meteorological Monographs, v. 8): Boston (American Meteorological Society), p. 37-62.

Worthington, L.V., 1970. The Norwegian Sea as a mediterranean basin, Deep-Sea Research, v. 17, p. 77-84.

Worthington, L.V., and Volkmann, G.H., 1965. The volume transport of Norwegian Sea overflow water in the North Atlantic, Deep-Sea Research, v. 12, p. 667-676.

Worthington, L.V., and Wright, W.R., 1970. North Atlantic Ocean Atlas, v. 2: Woods Hole Oceanographic Institution, Woods Hole, Massachusetts. 